\title{
MANAGING THE CREATIVE AND LABOR-INTENSIVE BUSINESS PROCESSES OF THE APPAREL INDUSTRY
}

\section{Andrea Dobrosavljević}

University of Belgrade, Technical faculty in Bor

Vojske Jugoslavije 12, 19210 Bor, Serbia

*e-mail: an.dobrosavljevic@gmail.com,PhD student

\author{
Stručni rad \\ UDC: 678:005.93 \\ doi: $10.5937 /$ tekstind1904058D
}

\begin{abstract}
Creative and labor-intensive character are the specificities of the garment industry that arise from the activities that take place within the process, primarily related to apparel manufacturing. The consideration of the problems of managing creative and labor-intensive processes in the framework of this paper is approached considering that the clothing industry is characterized by a number of different specificities. The factors that influence the adoption of business process management practices in accordance with these specifics have different effects on the optimal management of these business processes. Therefore, this paper describes the links between the factors influencing the adoption of business process management practices and the creative and labor-intensive processes of the clothing industry and establishes a theoretical basis for further study of this issue.
\end{abstract}

Key words: business process management, creative processes, labor-intensive processes, apparel industry.

\section{UPRAVLJANJE KREATIVNIM I RADNO-INTENZIVNIM POSLOVNIM PROCESIMA ODEVNE INDUSTRIJE}

Apstrakt: Kreativni i radno-intenzivni karakter predstavljaju specifičnosti odevne industrije koje proističu iz aktivnosti koje se odvijaju u okviru procesa, prevashodno vezanih za proizvodnju odeće. Razmatranju problematike upravljanja kreativnim i radno-intenzivnim procesima u okviru ovog rada se pristupa uzimajući u obzir to da odevnu industriju odlikuje niz različitih specifičnosti. Faktori od uticaja na usvojenost prakse upravljanja poslovnim procesima u skladu sa tim specifičnostima ostvaruju različiti uticaj na optimalno upravljanje ovim poslovnim procesima. Stoga se u okviru ovog rada se opisuju veze između faktora od uticaja na usvojenost prakse upravljanja poslovnim procesima i kreativnih i radno-intenzivnih procesa odevne industrije i uspostavlja teorijska osnova za dalja proučavanja ove problematike.

Ključne reči: upravljanje poslovnim procesima, kreativni procesi, radno intenzivni procesi, odevna industrija.

\section{INTRODUCTION}

Each industry carries with it specific characteristics that can determine how its business operates and how business practices are adopted. As Venkatesh et al. [1] suggest, organizations should have their own unique procedures that they apply in accordance with their own working conditions. Considering the business of the apparel industry, it is possible to notice a number of specifics, from the way business activities are carried out to the workforce structure. Apparel manufacturing is dependable on style, season, size and the like [2]. Therefore, the apparel industry provides an opportunity to explore various issues concerning management practices and business flows. Particular attention has been given to the business process management (BPM) in the apparel industry, 
given that the specifics related to this industry are reflected through the processes.

BPM is used in organizations as a method to increase awareness and knowledge of the business processes that take place within them [3]. Examples of business processes are most easily reflected in the order-to-delivery, procurement-to-payment or error-to-solution relations [4]. Business processes within apparel industry can be regarded as labor-intensive due to the need for the application of manual work and the existence of complex operations, but also as a creative one because the creative character of the clothing and fashion industry is emphasized $[5,6]$. Kucera and Tejani [7] find that textile and apparel industry exert the greatest influence on the intensity of work in South Korea, Taiwan, Malaysia, Morocco and Turkey by researching labor-intensive industries [8].

Organizational management of business processes is considered through the prism of efficiency and effectiveness of business processes, whether creative or labor-intensive [9]. BPM in organizations of apparel industry has a particularly important topic, not only because of the nature of business processes, but also because these business processes take place in most small and medium-sized enterprises. In Serbia, as in other European countries, the largest number of apparel organizations are small and medium-sized enterprises [10].

Taking into account the elements of the BPM practices application within the clothing industry, the paper focuses on the creative and labor-intensive character, as specificities of the apparel industry, which are reflected through process activities and can exert their influence on the way in which BPM is adopted. The aim of this paper is to identify the creative and labor-intensive processes of the clothing industry and the factors that can influence its optimal management.

\section{BUSINESS PROCESS MANAGEMENT ADOPTION FACTORS}

BPM involves the support of business processes using methods, techniques, software to design, deployment, control and analysis of operational processes, which involve people, multiple organizations, applications, documents and other sources of information [11]. The contexts of the application of BPM are different and may depend on different factors related to the nature of the industry and the organizations themselves $[12,13]$.
Modern organizations in all areas of business recognize the importance of simultaneously developing and aligning elements such as strategy, performance, technology, rules, information, knowledge, equipment, organization and human resources. Leading organizations align and integrate these elements with the help of processes as drivers [14]. Based on a holistic approach, many researchers look at a comprehensive set of factors that influence the success of BPM application [15].

Hayiheydari and Dabaghkashani [16] state that different critical success factors derived from different research studies have an impact on the success of implementing a BPM system. Exploring the critical success factors of business process management, Trkman [17] states strategy alignment, level of IT investments, process performance measurement, level of specialization of employees as factors based on contingency theory, implementation of organizational changes, appointment of process owners, implementation of changes and continuous improvement of systems as factors based on dynamic capabilities, and process standardization, computerization, automation, training and employee empowerment as factors based on task and technology adaptation theory [18]. Buh et al. [19] provide a list of the success factors in adopting BPM based on a literature review. The factors they cite start from the support and involvement of top management, continue with compliance factors of strategy, people, methods and methodologies, communication, information technology, organizational culture, project and change management, performance measurement, management structure, understanding of the concept of business process management, continuous improvement and, of course, clear definitions of process owners.

Therefore, it can be said that the initially mentioned elements are aligned with the critical success factors of BPM adoption. The success of BPM adoption within the characteristic processes of the apparel industry could be assessed by a comprehensive review of processes based on factors derived from the literature.

\section{CREATIVE AND LABOR-INTENSIVE CHARACTER OF APPAREL INDUSTRY PROCESSES}

Processes are a blueprint for performing service delivery or production activities and can be considered as the core of an organization [20, 21]. BPM, therefore, should be among priorities [22]. It can be noticed that the functioning of the processes is driven 
by a combination of human resources and technology [23].

Accordingly, the nature of the business processes of the apparel industry is characteristic. The basic stages of garment production are the design and tailoring of the pattern, material cutting, sewing, ironing and packaging of finished apparel. Sewing is the most critical business process in the apparel industry, with the largest number of operations. As part of this business process, tasks are assigned to employees according to the level of skills they possess [24]. Clothing is manufactured on a continuous production line in which pieces of material are consecutively passed through a network of workstations where skilled manual workers connect the forwarded pieces using a sewing machine, whereby active involvement of the employee in this process can be observed $[25,26]$. During this process, the speed of the component assembly process should be strictly controlled [27].

Tatsiopoulos et al. [28] based on Apparel Business Model represent a more disaggregated set of processes. They allocate 11 core business processes: garment design and collection creation, sampling and order processing, procurement, production order management, in-house ordering, subcontracting, in-house production coordination, sub-contracted production coordination, In-house goods handling and control, receipt of subcontracted goods and controls, packaging and delivery of goods. For the sake of ease of understanding the operations that contribute to the work intensity of the process, the research by the authors Kayar and Akyalçin [29], who break down the process of joining the T-shirt components by specifying the mode of operation for each of the separate operations, as well as the order of operations, is stated and represented in figure 1.

The presented descriptions of the steps in the process of apparel manufacturing serve to visualize the position of creativity and labor-intensity characteristics. Operations within the apparel industry are accompanied by a high level of the workload with constant repetition of the same movements due to the repetition of the operation; while inadequate working conditions are also present [30]. This makes

\begin{tabular}{|c|c|}
\hline Shoulder s ewing & 4 thread over lock machine \\
\hline Collar ins eam & Lock-stitch sewing machine \\
\hline Collar s ewing & 4 thread over lock machine \\
\hline Neck label sewing & Lock-stitch sewing machine \\
\hline Neck binding s ewing & Chain stitch sewing machine \\
\hline Bind ing control - regulated & Hand-made \\
\hline Sleeve sewing & 4 thread over lock machine \\
\hline Care label preparing & Lock-stitch sewing machine \\
\hline Side seam & 4 thread over lock machine \\
\hline Sleeve hem cover s eem & Blade cover stich machine \\
\hline Sleeve hem reinforcement & Lock-stitch sewing machine \\
\hline Hem cover seam & Blade cover stich machine \\
\hline Hem reinforcement & Lock-stitch s ewing machine \\
\hline Flag label s ewing & Lock-stitch sewing machine \\
\hline Ironing & Iron \\
\hline
\end{tabular}

Figure 1: Operations as part of the T-shirt component sewing process [29] 
the clothing industry a labor-intensive industry in which low wages are paid to employees [31]. In the clothing companies, production workers occupy the largest share in the workforce structure. In addition, there is a dominant share of the female employees $[32,33]$. The literature mentions that modelers and sewing machine operators are key workers in the production of garments [34,35]. Processes within this industry can be considered labor-intensive due to the presence of a large number of manual operations. The basic operations within the clothing industry are material cutting, sewing and finishing. Due to the need for manual handling of machines and materials, automation is limited [36].

Joining of components, that is, the sewing process, represents the most demanding and at the same time the central process of production of garments $[37,38]$. The sewing tasks of the components on the sewing machine are performed in a sitting position by pushing larger pieces of fabric with the left hand forward with the stitching under the sewing foot of the machine with the right hand. Due to the design of the machine and the needle position, the operator must take an inclined position of the body and neck in order to have a clear view of what he is doing [39].

The creative process is generally seen as an uninterrupted process, free and without restriction. The role of the designer is important in the initial stages of the creative process. He identifies and adapts future trends to design ideas and sketches of the new collection [40]. Creativity itself is the input of the creative process, and the result of the process is shaped by this input [41]. Product design and production planning are critical business processes in a collaborative environment [42]. It can also be said that the creative process never ends because textile and apparel companies cyclically repeat processes and activities while implementing changes in product design in line with current fashion trends [43].

Dieffenbacher [44] presents an illustration of the design cycle, while stating that designers should take ownership, not only of their ideas but also of the whole process.

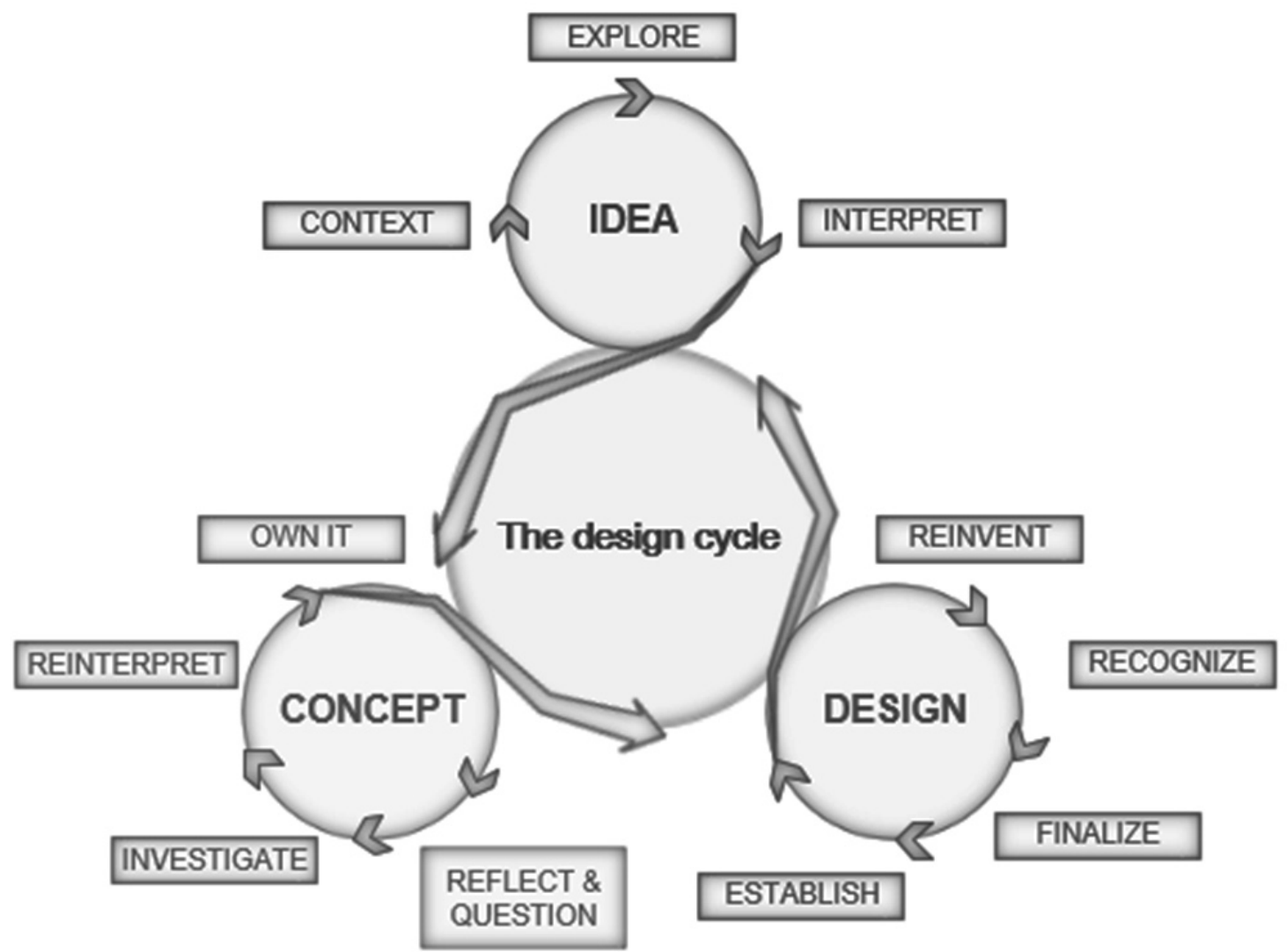

Figure 2: Visualization of the creative process through an illustration of the design cycle by Dieffenbacher [44] 


\section{FACTORS OF THE ACQUISITION OF CREATIVE AND WORK-INTENSIVE PROCESSES MANAGEMENT IN THE APPAREL INDUSTRY}

The issue of the adoption of BPM practices in the apparel industry is accompanied by a number of specifics, among which is the character of business processes in accordance with the characteristics of operations performed within those processes, as already explained in the previous chapters. Various authors have dealt with the isolation of critical factors in the adoption of this practice; however, there is a need to consider the connection of these factors with the characteristic creative and labor-intensive processes of the apparel industry. The literature review identifies factors related to top management's active involvement in business process management, strategy alignment with process functioning, human resources issues, communication and organizational culture, process role structure and definition, modernization and implementation of information technologies, current status evaluation and establishment of a system of continuous improvement. The elements of the representation of these factors in the processes of the clothing industry are distinguished based on a review of available literature.

Poor commitment, as well as a lack of understanding of top management, is seen as a challenge and a barrier to adopting new management practices or establishing a system of continuous improvement. $[45,46]$. SMEs in the textile and apparel sector in Serbia are mostly privately owned [47]. In small businesses, ownership is combined with management or management is entrusted to family members, with subjectivity in decision making on many business issues [48, 49].

Bearing in mind the strategy's compliance factor, it should be emphasized that in order to respond to consumer demands, organizations must transform their key, or core, business processes into strategic capabilities. [50]. According to Kabukcu [51] the creative process consists of preparation, exploration, transformation, incubation, illumination, verification and implementation. Karpova et al. [52] states that professionals in the creative industries observe, practice, exchange, adapt and nurture 32 creative strategies as part of their daily lives.

The labor-intensive process is aimed at achieving a higher level of productivity with the active involvement of the workforce and the application of manual work in operational processes [53]. With such labor-intensive technological processes and operations within them, employees are exposed to different influences [54]. Employees play a significant role in process-oriented organizations because they not only carry out effective implementation of activities within business processes but are also there to ensure successful implementation of change, therefore the issue of human resources development is becoming more important $[55,56]$. Qualified staff are essential, in both the manufacturing and management processes of the textile and clothing industries [57]. Employee capabilities are important to the success of an organization because of the way in which they perform operations affects the quality of process outputs [58].

Culture is considered to be a factor that influences different elements of the management process with the formation of an environment that facilitates the implementation of different BPM initiatives [55]. Organizational culture is manifested through the typical characteristics of an organization. It represents the deep-rooted values and beliefs that the staff of the organization shares [59]. Hribar and Mendling [22] note that organizational culture is one of the most important factors in managing business processes. More attention should be paid to the study of organizational culture as part of managing the specific creative and labor-intensive processes of the clothing industry.

Performance measurement plays an important role as it provides the necessary information for decision-making. On this basis, it is necessary to measure the right things at the right time in the supply chain [58]. Managers of labor-intensive organizations should make deeper assessments and explore opportunities for improvement by applying a combination of different methods of measuring performance [60].

Business process management has been developed emphasizing the adoption of information technology [57]. Scott [61] considers the apparel industry as a labor-intensive industry that implements low technology in manufacturing. Modern trends and new technologies are finding their way to traditional industries such as apparel [62]. Modern trends are causing a number of changes in business, especially when it comes to modernization of technological equipment, simplification, and acceleration of the production process. BPM is an approach to improving the performance of organizations with the combination of information technology with processes and management methods and requires collaboration between business people and information technology to foster efficient, agile and transparent business processes [63]. 


\section{CONCLUSION}

The apparel industry exudes specifics that can affect the adoption of business practices. Their impact can be reflected in difficult conditions or suitable soil for adoption and successful establishment of practices. On the basis of this work, the adoption of business process management practices was examined based on two specific characteristics of the garment industry, creativity, and work-intensity. The creative and labor-intensive character is attributed to the processes that take place in the production of garments. A review of the research conducted so far has examined the representation of factors influencing the adoption of business process management within the processes characterized by the apparel industry. Based on the review of available research, the need to conduct a more detailed study of the relationships between the factors of BPM adoption and the creative and labor-intensive processes of the clothing industry has been identified. Further research needs to examine the extent to which the representation of individual factors indicates the degree of adoption of BPM practices in clothing SMEs. It is necessary to evaluate the influence of the factors themselves based on the specificity of the clothing industry, and develop a model of adoption of BPM practices based on the specificity of the clothing industry in the region.

\section{LITERATURE}

[1] Venkatesh, V. G., Dubey, R., Aital, P. (2014). Analysis of sourcing process through SAP-LAP framework-a case study on apparel manufacturing company. International Journal of Procurement Management, 7(2), 145-167.

[2] Syduzzaman, S., Rahman, M., Islam, M., Habib, A., Sharif, A. (2014). Implementing total quality management approach in garments industry. European Scientific Journal, 10(34).

[3] Malinova, M., Mendling, J. (2012). A qualitative research perspective on BPM adoption and the pitfalls of business process modeling. In International Conference on Business Process Management, Springer, Berlin, Heidelberg, 77-88.

[4] Janiesch, C., Koschmider, A., Mecella, M., Weber, B., Burattin, A., Di Ciccio, C., Gal, A., Kannengiesser, U., Mannhardt, F., Mendling,J., Oberweis, A., Reichert, M., Rinderle-Ma, S., Song, W., Su, J., Torres, V., Weidlich, M., Weske, M., Zhang, L. (2017). The internet-of-things meets business process management: mutual benefitsanh chalenges. pp. 1-9 available: https://arxiv.org/pdf/1709.03628.pdf
[5] Tewari, M. (2006). Adjustment in India's textile and apparel industry: reworking historical legacies in a post-MFA world. Environment and Planning A, 38(12), 2325-2344.

[6] Aspers, P., Skov, L. (2006). Encounters in the global fashion business: Afterword. Current Sociology, 54(5), 802-813.

[7] Kucera, D., Tejani, S. (2014). Feminization, defeminization, and structural change in manufacturing. World Development, 64, 569-582.

[8] Huang, Y., Ma, Y., Yang, Z., Zhang, Y. (2016). A Fire Sale without Fire: An Explanation of Labor-Intensive FDI in China. Journal of Comparative Economics, 44(4), 884-901.

[9] Schmiedel, T., vom Brocke, J., Recker, J. (2015). Culture in business process management: how cultural values determine BPM sucess. In Handbook on Business Process Management, Berlin, Heidelberg, 649 $-663$.

[10] Đorđević, D., Urošević, S., Cvijanović, J. M. (2010). Uloga klastera u unapređivanju konkuretnosti tekstilne i odevne industrije u Republici Srbiji. Industrija, 38(2), 177-198.

[11] Weske, M., van der Aalst, W. M., Verbeek, H. M. W. (2004). Advances in business process management. Data \& Knowledge Engineering, 50(1), 1-8.

[12] vom Brocke, J., Zelt, S., Schmiedel, T. (2016). On the role of context in business process management. International Journal of Information Management, 36(3), 486-495.

[13] deBruin, T. (2007). Insights into the Evolution of BPM in Organisations. ACIS 2007 Proceedings, 43.

[14] Burlton, R. (2011). BPM critical success factors lessons learned from successful BPM organizations. Business Rules Journal, 12(10), 1-6.

[15] Schmiedel, T., vom Brocke, J., \& Recker, J. (2015). Culture in business process management: how cultural values determine BPM success. In Handbook on Business Process Management 2, Springer, Berlin, Heidelberg. 649-663.

[16] Hajiheydari, N., Dabaghkashani, Z. (2011). BPM implementation critical success factors: applying meta-synthesis approach. In Proceedings of the 2011 International Conference on Social Science and Humanity, 5, Singapore, 38-43.

[17] Mertens, W., Van den Bergh, J., Viaene, S., Schroder-Pander, F. (2011, January). How BPM impacts 
jobs: an exploratory field study. In 2011 44th Hawaii International Conference on System Sciences pp. 1-10.

[18] Trkman, P. (2010). The critical success factors of business process management. International journal of information management, 30(2), 125-134.

[19] Buh, B., Kovačič, A., Indihar Štemberger, M. (2015). Critical success factors for different stages of business process management adoption-a case study. Economic Research-Ekonomska Istraživanja, 28(1), 243-257.

[20] Muellerleile, T., Ritter, S., Englisch, L., Nissen, V., Joenssen, D. W. (2015). The influence of process acceptance on BPM: an empirical investigation. In 2015 IEEE 17th conference on business informatics, Vol. 1, pp. 125-132.

[21] Willaert, P., Van Den Bergh, J., Willems, J., Deschoolmeester, D. (2007). The process-oriented organisation: a holistic view developing a framework for business process orientation maturity. In International Conference on Business Process Management, Springer, Berlin, Heidelberg, 1-15.

[22] Hribar,B., Mendling, J. (2014). The Correlation of OrganizationaL Culture and Success of BPM Adoption", Proceedings of the European Conference on Information Systems (ECIS) 2014, Tel Aviv, Israel, June 9-11.

[23] Bulander, R., Dietel, M. (2013). The consideration of organizational, human and corporate cultural factors in the implementation of business process management projects: Social factors to prevent failure of BPM projects. In 2013 International Conference on e-Business (ICE-B), 1-9.

[24] Chen, J. C., Chen, C. C., Lin, Y. J., Lin, C. J., Chen, T. Y. (2014). Assembly line balancing problem of sewing lines in garment industry. In Proceedings of the 2014 International Conference on Industrial Engineering and Operations Management Bali, Indonesia, 7-9.

[25] Spragg, J. E., Fozzard, G., Tyler, D. J. (1997). Constraint based reactive rescheduling in a stochastic environment. In European Conference on Planning, Springer, Berlin, Heidelberg, 403-413.

[26] Hoffman, K., Rush, H. (1982). Microelectronics and the Garment Industry: not yet a perfect fit. The IDS Bulletin, 13(2), 35-41.

[27] Kitaw, D., Matebu, A., Tadesse, S. (2010). Assembly line balancing using simulation technique in a garment manufacturing firm. Zede Journal, 27, 69-80.
[28] Tatsiopoulos, I. P., Ponis, S. T., Panayiotou, N. A. (2002). e-business in the Greek Apparel Industry: A proposed business model. Operational Research, 2(1), 93-108.

[29] Kayar, M., Akyalçin, Ö. C. (2014). Applying different heuristic assembly line balancing methods in the apparel industry and their comparison. Fibres \& Textiles in Eastern Europe, 22 (6 (108)), 8-19.

[30] Polat, O., Kalayci, C. B. (2016). Ergonomic Risk Assessment of Workers in Garment Industry. In Eight International Conference on Textile Science \& Economy VIII, Zranjanin, Sarbia, 16-21.

[31] Yunus, M., Yamagata, T. (2012). The garment industry in Bangladesh. Dynamics of the Garment Industry in Low-Income Countries: Experience of Asia and Africa (Interim Report). Chousakenkyu Houkokusho, IDE-JETRO.

[32] Taplin, I. M. (1996). Rethinking flexibility: The case of the apparel industry. Review of Social Econo$m y, 54(2), 191-220$.

[33] Urošević, S., Đorđević, D., Cvijanović, J. M. (2009). Značaj doradnih poslova za razvoj tekstilne $\mathrm{i}$ odevne industrie Srbije u procesu tranzicije. Industrija, 37(2), 97-125.

[34] Taplin, I. M., Winterton, J., Winterton, R. (2003). Understanding labour turnover in a labour intensive industry: evidence from the British clothing industry. Journal of Management Studies, 40(4), 10211046.

[35] Staples, N. J. (1993). Job design of patternmakers in apparel manufacturing. Clothing and Textiles Research Journal, 11(2), 7-15.

[36] Varukolu, V., Park-Poaps, H. (2009). Technology adoption by apparel manufacturers in Tirupur town, India. Journal of Fashion Marketing and Management: An International Journal, 13(2), 201-214.

[37] Bahadir, S. K. (2011). Assembly line balancing in garment production by simulation. In Assembly Line-Theory and Practice. IntechOpen.

[38] Kursun, S., Kalaoglu, F. (2009). Simulation of production line balancing in apparel manufacturing. Fibres \& Textiles in Eastern Europe, 17(4(75)), 6671.

[39] Halpern, C. A., Dawson, K. D. (1997). Design and implementation of a participatory ergonomics program for machine sewing tasks. International journal of industrial ergonomics, 20(6), 429-440. 
[40] Jeacle, I., Carter, C. (2012). Fashioning the popular masses: accounting as mediator between creativity and control. Accounting, Auditing \& Accountability Journal, 25(4), 719-751.

[41] Karpova, E., Marcketti, S., Kamm, C. (2013). Fashion industry professionals' viewpoints on creative traits and, strategies for creativity development. Thinking Skills and Creativity, 10, 159-167.

[42] Bakht, Z., Salimullah, M., Yamagata, T., Yunus, M. (2006). Competitiveness of a labor-intensive industry in a least developed country: A case of the knitwear industry in Bangladesh. mimeographed, Chiba, Japan: Institute of Developing Economies.

[43] Patora-Wysocka, Z. (2015). Inhibitors of restructuring change in Textile and apparel enterprises. Fibres \& Textiles in Eastern Europe, 23(5 (113)), 8-12.

[44] Syduzzaman, M., Islam, M. M., Habib, M. A., Yeasmin, D. (2016). Effects of implementing TQM principles in the apparel manufacturing industry: case study on a Bangladeshi clothing factory. Science and Technology, 6(3), 68-75.

[45] Bashar, A., \& Hasin, M. A. A. (2017). Nonlinear correlation of top management commitment with organizational performance in the apparel industry of Bangladesh. North South Business Review, 7(2), 17-27.

[46] Urošević, S. (2011). Koncept klaster-rešenje za opstanak malih i srednjih preduzeća u sektoru tekstila. Zbornik radova Tehnološkog fakulteta, Leskovac, 252-260.

[47] Fuller-Love, N. (2006). Management development in small firms. International Journal of Management Reviews, 8(3), 175-190.

[48] Carney, M. (1998). A management capacity constraint? Obstacles to the development of the overseas Chinese family business. Asia Pacific journal of management, 15(2), 137-162.

[49] Shamsuzzoha, A., Kankaanpaa, T., Carneiro, L. M., Almeida, R., Chiodi, A., Fornasiero, R. (2013). Dynamic and collaborative business networks in the fashion industry. International Journal of Computer Integrated Manufacturing, 26(1-2), 125-139.

[50] Kabukcu, E. (2015). Creativity process in innovation oriented entrepreneurship: The case of Vakko. Procedia-Social and Behavioral Sciences, 195, 1321-1329.
[51] Luo, J., Fan, M., Zhang, H. (2015). Information technology, cross-channel capabilities, and managerial actions: Evidence from the apparel industry. Journal of the Association for Information Systems, Forthcoming, 2016-056.

[52] Islam, S., Shazali, S. S. (2011). Determinants of manufacturing productivity: pilot study on laborintensive industries. International Journal of Productivity and Performance Management, 60(6), 567-582.

[53] Stefanović, V. (2018). Uticaj uslova radne sredine za zadovoljstvo zaposlenih u tekstilnoj industriji. Tekstilna industrija, 66(1), 55-63.

[54] Wojtczuk-Turek, A. (2014). The Role of Organizational Culture and Human Capital Management in Process Organization. Zeszyty Naukowe Uniwersytetu Szczecińskiego. Scientific Journal. Service Management, 14, 39-48.

[55] Ali, M. H., Opatha, H. H. D. N. P. (2008). Performance appraisal system and business performance: an empirical study in Sri Lankan apparel industry. Sri Lankan Journal of Human Resource Management, 1(2), 74-90.

[56] Kokeza, G., Urošević, S., Radosavljević, D. (2016). Razvoj kompetencija zaposlenih kao element menadžmenta ljudskih resursa - sa posebnim osvrtom na tekstilnu industriju. Tekstilna industrija, 64(4), 7283.

[57] Lee, K. L., Mohamed Udin, Z., Hassan, M. G. (2014). Global supply chain capabilities in Malaysian textile and apparel industry. International Journal of Supply Chain Management (IJSCM), 3(2), 31-40.

[58] Sun, S. (2008). Organizational culture and its themes. International Journal of Business and Management, 3(12), 137-141.

[59] Karim, A., Arif-Uz-Zaman, K. (2013). A methodology for effective implementation of lean strategies and its performance evaluation in manufacturing organizations. Business Process Management Journal, 19(1), 169-196.

[60] Moges Belay, A., Moges Kasie, F., Helo, P., Takala, J., J. Powell, D. (2014). Adoption of quality management practices: An investigation of its relationship with labor productivity for labor-intensive manufacturing companies. Benchmarking: An International Journal, 21(1), 77-100.

[61] Scott, A. J. (2006). The changing global geography of low-technology, labor-intensive industry: 
clothing, footwear, and furniture. World Development, 34(9), 1517-1536.

[62] Gazova, A., Papulova, Z., Papula, J. (2016). The application of concepts and methods based on process approach to increase business process efficiency. Procedia Economics and Finance, 39, 197205.
[63] Van Greunen, D., Van Der Merwe, A., Kotze, P. (2010). Factors influencing BPM tools: The influence on user experience and user interfaces. International Journal of Computing and ICT Research, 4(1), 47-57.

Rad primljen: 25.09.2019.

Rad prihvaćen: 21.11.2019. 